\title{
GROUNDWATER IRRIGATION ECONOMY OF HARYANA: A GLIMPSE INTO SPREAD, EXTENT AND ISSUES
}

\author{
Amrita Kasana \\ and \\ Omvir Singh*
}

\begin{abstract}
Since the inception of Green Revolution in India, Haryana has emerged as one of the major users of groundwater in irrigation sector. Irrigation supplied by groundwater played a vital role in agricultural transformation, food security and livelihoods of the country in general and of the State in particular. However, very limited research on groundwater irrigation economy of Haryana has been conducted till now. Therefore, the present study based on both primary and secondary data has been conducted to highlight the various facets of groundwater economy in agriculture dominated State of Haryana. The obtained results indicate that the density of tube wells per thousand hectares and number has increased by more than 250 and 300 per cent, respectively, during 1975 to 2013. The area under hired irrigation through tube wells is also increasing. In spite of remarkable increase in number of commercial and cooperative banks in the State, they account for only about 15 per cent of the total loans disbursed for tube well installation. Bulk of tube wells (70 per cent) are owned by small farmers and it is contrary to the belief that the benefit of electricity subsidy goes only to large farmers who are most likely to have large number of own electric tube wells. Finally, the findings of the study reflect that the groundwater irrigation economy in Haryana is in growth phase and it is important to understand fully the dynamics of this economy before the managers and policy makers may begin to think about effectively managing it.
\end{abstract}

*Department of Geography, Kurukshetra University, Kurukshetra-136119, India, Email: ovshome@yahoo.com; ovshome@gmail.com.

Journal of Rural Development, Vol. 36, No. 4, October-December : 2017 


\section{Introduction}

Groundwater is generally considered to be the most productive irrigation source due to itsreliability of supply and availability on demand. The use of ground water for irrigated agriculture in rural India has a long history. However, the area of irrigated crop land using ground water has expanded rapidly with diffusion of Green Revolution technology in India. Irrigation from groundwater grew by a factor of over four during 1960-1999 period and currently represents over half of the country's irrigated area (Dubash,2000; Scott and Sharma, 2009). Introduction of modern drilling techniques, electric operated pumping systems, availability of electricity at nominal or no price and absence of effective ground water legislation had promoted uncontrolled use of ground water in the country (Patle et al., 2015). Furthermore, there are about 82 million farm households in India, out of which 21 million households have their own water extraction mechanisms (WEMs), while another 24 million employed hiring of irrigation services from others (Mukherji, 2007). Apart from this, rapid development of groundwater resources is becoming a major concern in the western IndusGanges Basin (Pakistan and the Indian States of Punjab, Haryana and Uttar Pradesh), as it has led to decline in groundwater levels. This decline in groundwater levels has, in turn, led to drying up of dug wells and increasing well failurescausing higher costs of installing new tube wells, deepening of existing wells and maintenance activities (Moench, 1992). Competitive deepening of wells makes the distribution of access to groundwater increasingly skewed in favour of large and resource-rich farmers, leaving the resource out of race for the poor farmers (Shah, 1993; Saleth, 1996). Under this scenario, groundwater markets have emerged as an alternative water management strategy for making equitableand efficient use of scarce water resources (Shah, 1993).

Since the emergence of pumped groundwater irrigation, localised informal sale and purchase of groundwater, extracted through WEMs, has evolved as agrarian institution globally, particularly in India (Mukherji,2007;2008). This informal sale and purchase of groundwater, extracted through WEMs, is henceforth referred as "groundwater markets" for the sake of brevity and convenience. However, informal ground water markets in India are quite different from the formal groundwater markets found in parts of USA, Australia and Chile (Bjornlund and McKay, 2002). Recently, such informal trading in ground water has also started to emerge in China, as a result of privatisation of erstwhile village community-owned wells and tube wells (Zhang et al., 2008). A large body of literature both in water-scarce regions as well as in waterabundant areas exists that discusses various dimensions of groundwatermarkets, such astheir informal, localised and fragmented nature, on the one hand and their spread, extent, mode of functioning and the impact they have on agrarian economy, on the other hand (Shah, 1993; Shah and Ballabh, 1997; Singh, 2002; Sharma and Sharma, 2004; Prakash, 2005; Mukherji, 2006, 2007, 2008; Shah et al., 2006; Dubey and Rai, 2008; Scott and Sharma, 2009). These studies have a limited spatial coverage, covering a few 
villages and hence fail to generate a macro picture of spread and extent of the groundwater markets at regional, national and global scale.

Among the Indian States, Haryana, located in north-western part of the country, is basically an agricultural State and groundwater plays an important role in theeconomic development and ecological balance of the State. Therefore, the State has seen tremendous increase in groundwater use for agriculture in the past few decades (Bhalla, 2007; Hira, 2009). Haryana State with only 1.4 per cent of the total geographical area of the country is contributing about 7 per cent of the India's food production. Irrigation supplied by groundwater, played a vital role in agricultural transformation of the State. Net irrigated area in Haryana increased from 1.2 million ha in 1966-67 to 3.1 million ha in 201213 of which the share of groundwater has increased from 0.6 million ha to 1.7 million ha. During the same time period, area under surface water irrigation (canals) increased from 0.9 million hato 1.3 million ha. In fact, over the years, area under groundwater irrigation has grown steadily, while the area under surface water irrigation has either stagnated or even declined (Figure 1). Similarly, the share of tube well irrigated area to the total irrigated area increased from 38.9 percent in 1975-76 to 61.2 percent in 2011-12 (Singh and Amrita, 2015) leading to more agricultural output than that from all other sources of irrigation put together in the State. Apart from this, the number of tube wells in the State has increased from 0.02 million in 1966 to 0.73 million in 2012. This expansion of groundwater for irrigational use at such an alarming level led to sharp depletion of the resource and compels the farmers to shift their shallow tube wellsinto deep tube wells (Chawla et al.,2010). However,many farmers are not able to invest for the installation of deep tube wells as it necessitates big investment and, therefore, buy water from other farmers. This kind of informal ground water markets have become a feature of State's agriculture economy. In spite of various insightful studies on groundwater markets globally as well as in India, very limited research on ground water irrigation economy in Haryana has been conducted until now. Therefore, to fill the research gap, the present study has been undertaken to highlight the variouscharacteristics of groundwater economy in agriculture dominated State of Haryana for a better understanding of sustainability of ground water resources, leading to food security of the country in general and of the State of Haryana in particular. 
Figure 1: Growth of Net Irrigated Area in Haryana During 1966-67 and 2012-13

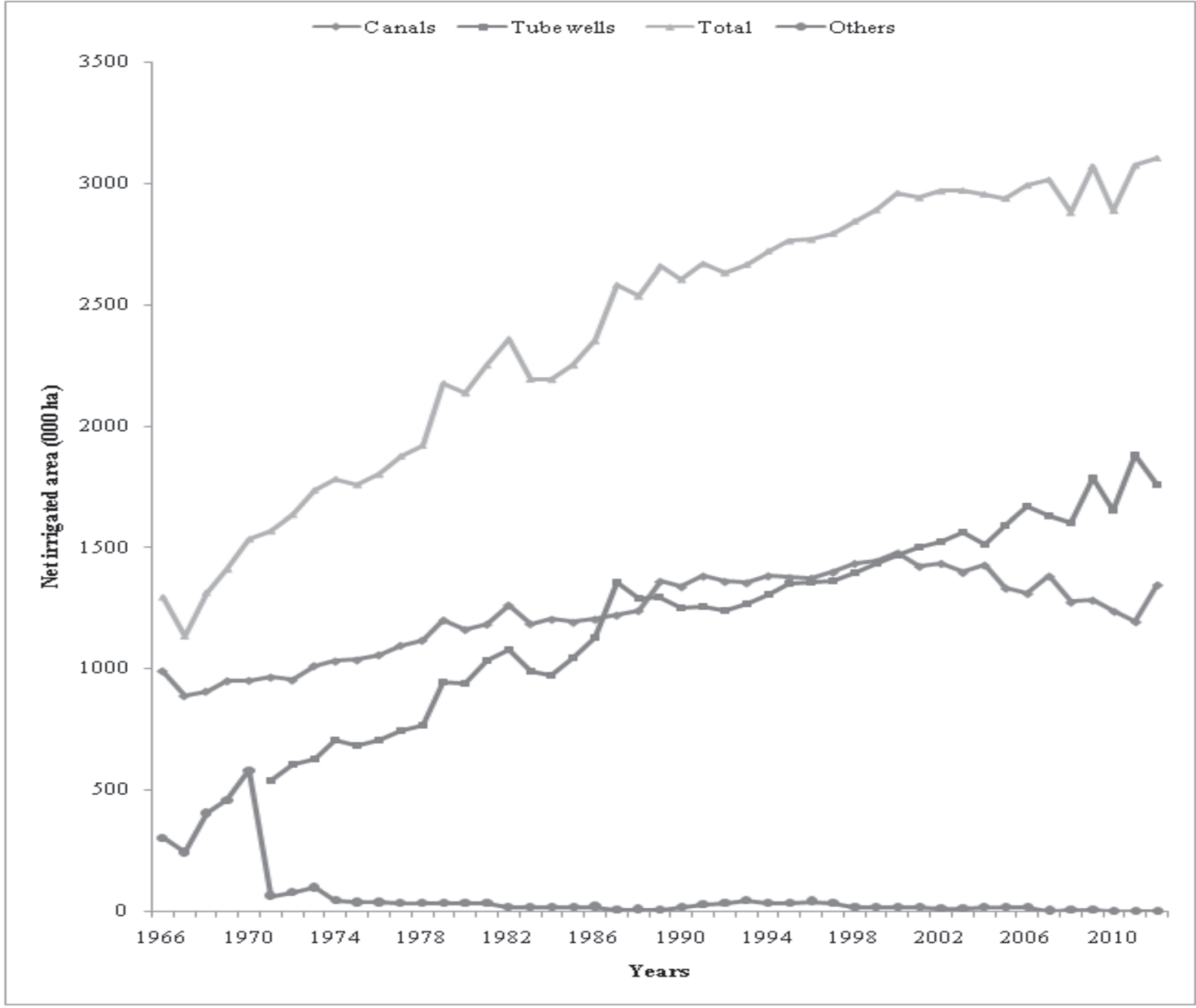

\section{Study Area}

The study area is the State of Haryana in north-western India, which extends between latitudes $27^{\circ} 39^{\prime}$ and $30^{\circ} 55^{\prime} \mathrm{N}$ and longitudes $74^{\circ}$ $28^{\prime}$ and $77^{\circ} 36^{\prime} \mathrm{E}$ (Figure 2).The State covers a geographical area of about $44212 \mathrm{~km}^{2}$ accounting about 1.4 percent of the total area of the country. Administratively, it comprises 21 districtsand 118 Community Development (CD) blocks. Physically, the State falls into three broad divisions namely, the Sub-Himalayan Tract,IndoGangetic Plain and Out-liers of Aravali Hills. The general slope of the ground isfrom north to south but the slopes become reverse further south and south-west due to presence of subdued ranges of the Aravalis. The soil texture of the State comprised 55 per cent sandy loam, 30 per cent loamy sand, 10 per cent loamy and 5 per cent sandy, which are generally favourable for a variety of crops such as rice, maize, jowar and sugarcane during kharif and wheat, barley and mustard during the rabi seasons. The climate is arid to semi-arid with an annual average rainfall of 455 $\mathrm{mm}$. Around 80 per cent of rainfall is received 
during J une to September, while the remaining is received during winter period from December to February. The western Yamuna canal and Bhakra canal system are the main surface irrigation systems, providing irrigation to crops. Apart from this, the State has an extensive minor irrigation system in the form of tube wells exploiting large quantities of groundwater.

Figure 2: The Geographic Location of the Study Area with Districts and Climatic Zones

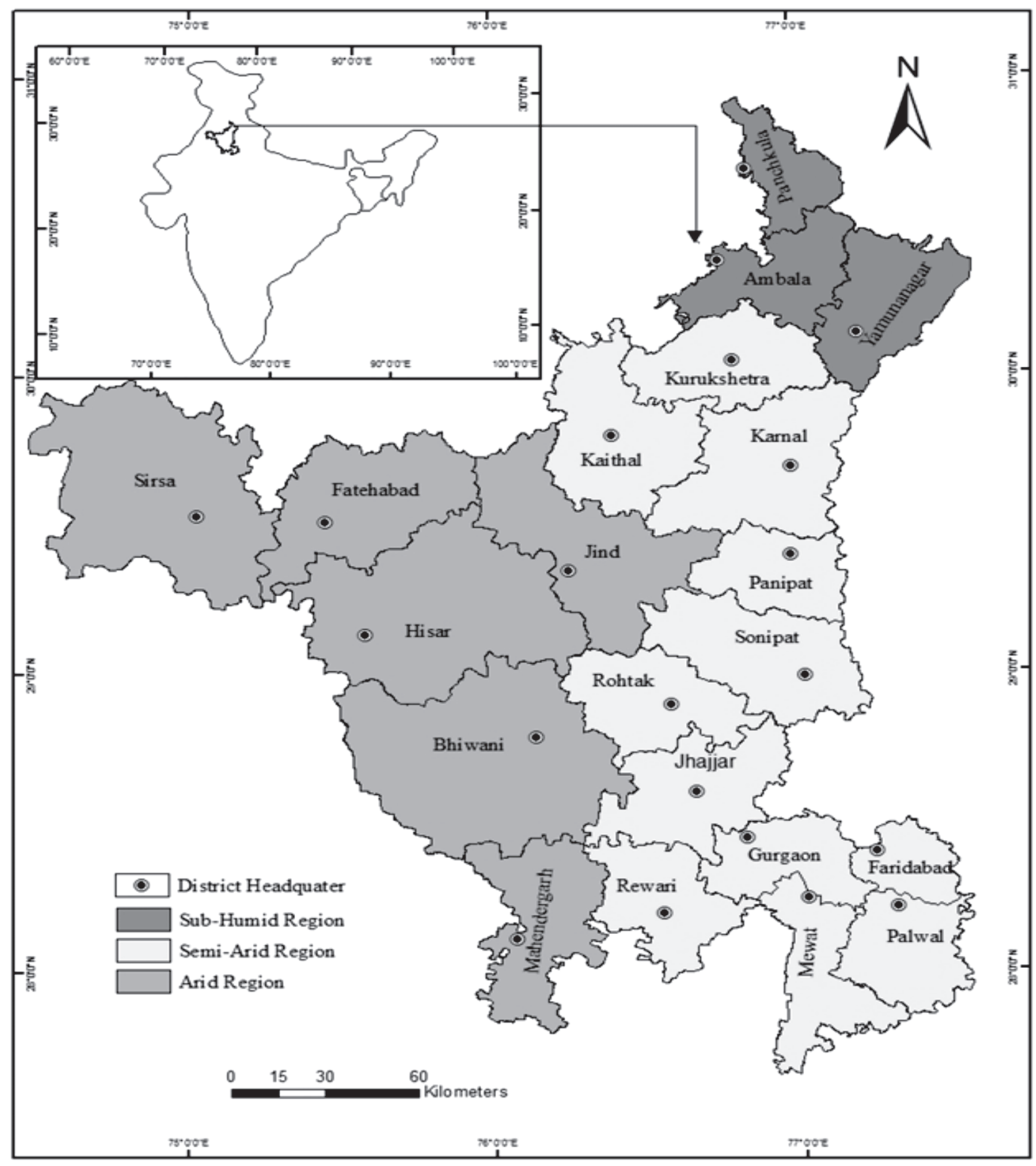

Journal of Rural Development, Vol. 36, No. 4, October- December : 2017 


\section{Methodology}

The present study is based on both primary and secondary data. The primary data were collected through a questionnaire survey of randomly selected 360 farmers across Haryana to get the details about different sources of financing used for the installation of their tube wells. The secondary data for the study were collected from various published reports of government and non-government organisations and the records of the Directorate of Economics and Statistics, Ministry of Agriculture, New Delhi and Department of Economic and Statistical Analysis, Haryana. These records highlight the cost of crop cultivation including irrigation for different crops grown, yield of crops, number of tube well owners, etc. These data are the only reliable official sources pertaining to groundwater economy for the State of Haryana. The data, thus, generated were analysed by means of standard mathematical and statistical tools. Furthermore, number and density of tube wells, area under hired and owned irrigation, farmers with owned and hired irrigation, different crops grown and their yield through owned and hired irrigation were made for every district, region and category of farmers classified according to the size of their landholdings. Farmers were classified as small (up to 2 hectares), medium (2-4 hectares) and large (4 hectaresor more) (Singh and Singh, 2015). Forcomputing regional variations, the 21 districts of Haryana have been divided into three regions such as sub-humid (Ambala, Panchkula and Yamunanagar), semi-arid (Faridabad, Gurgaon, J hajjar,Kaithal,Karnal,Kurukshetra,Mewat,Palwal, Panipat, Rewari, Rohtak and Sonipat), and arid
(Bhiwani, Fatehabad, Hisar, ind, Mahendergarh and Sirsa) (Raju et al., 2013).

\section{Results and Discussion}

Historical Development of Tube Well Irrigation: The utilisation of groundwaterfor irrigation has a long history in Haryana. The first phase covers the period up to 1970, when the traditional sources of irrigation continued to be significant. Groundwater withdrawal by means of Persian wheels from the dug wells accounted for about 25 percent of the net irrigated area. Next phase includes the period of 1970-90, when dependency on dug wells declined rapidly and the area irrigated through tube wells has increased from 34 to 48 per cent, registering a growth of 132.4 per cent. This tremendous growth in tube well irrigated area in the State can be attributed to declining discharges in canals, on theone hand and increasing demand fortimely and adequate amount of water due to introduction of package technology and greater productivity of crops, on the other hand. This compelled farmers to install their own tube wells during this phase. By the turn of century, tube well irrigated area toppled the canal irrigated area, dominant mode of irrigation till 2000 (Figure 1) Apart from this, policy of the government such as cost- effectiveness of electric tube wells, free boring scheme and flat tariff rates encouraged the rapid growth of tube wells in the State (Figure $3)$. Further, installation cost of tube wells encouraged the farmers to operate their tube wells at a high level of capacity utilisation by supplying irrigation water to other farmers. Thus arose a new institution of tube well irrigation markets or groundwater markets in the State. 
Figure 3: Growth of Tube Wells in the State of Haryana During 1974-75 and 2012-13

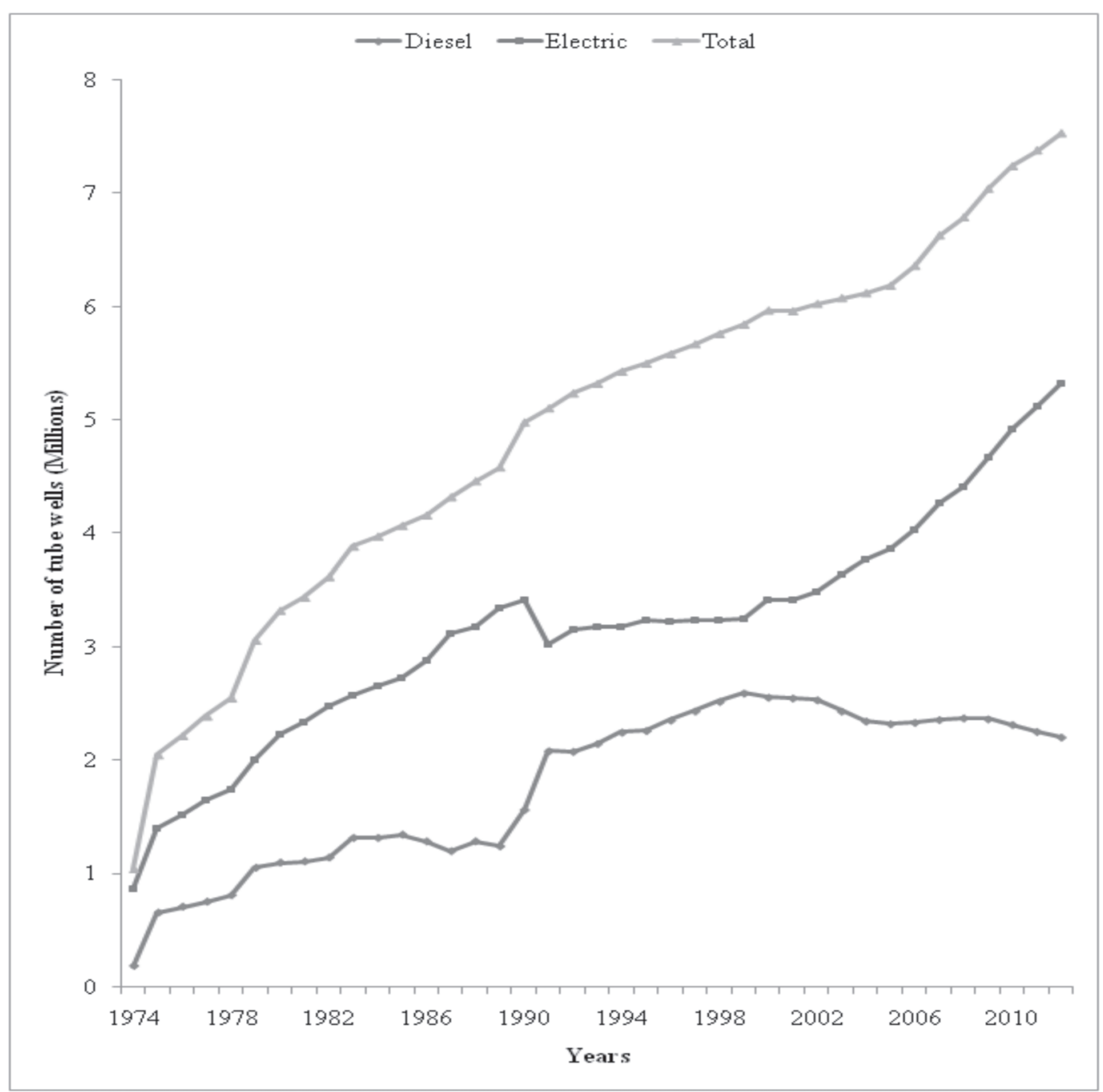

Number and Density of Tube Wells: The number of tube wells (electric and diesel) has increased by more than 300 per cent during the period 1974-75 to 2012-13, while the density per thousand hectares during the same period has increased from 46 to 170 (Figure 4). This tremendous growth in tube well number and density clearly demonstrates the increasing role of groundwater in the development of irrigated agriculture. Apart from this, the density of electric-operated tube wells in the State has increased continuously as a result of higher demand. Indeed, this reflects the impact of State government's concerted efforts such as flat tariff rates of electricity after economic liberalisation. 
Figure 4: Density of Tube Wells in Haryana During 1974-75 and 2012-13

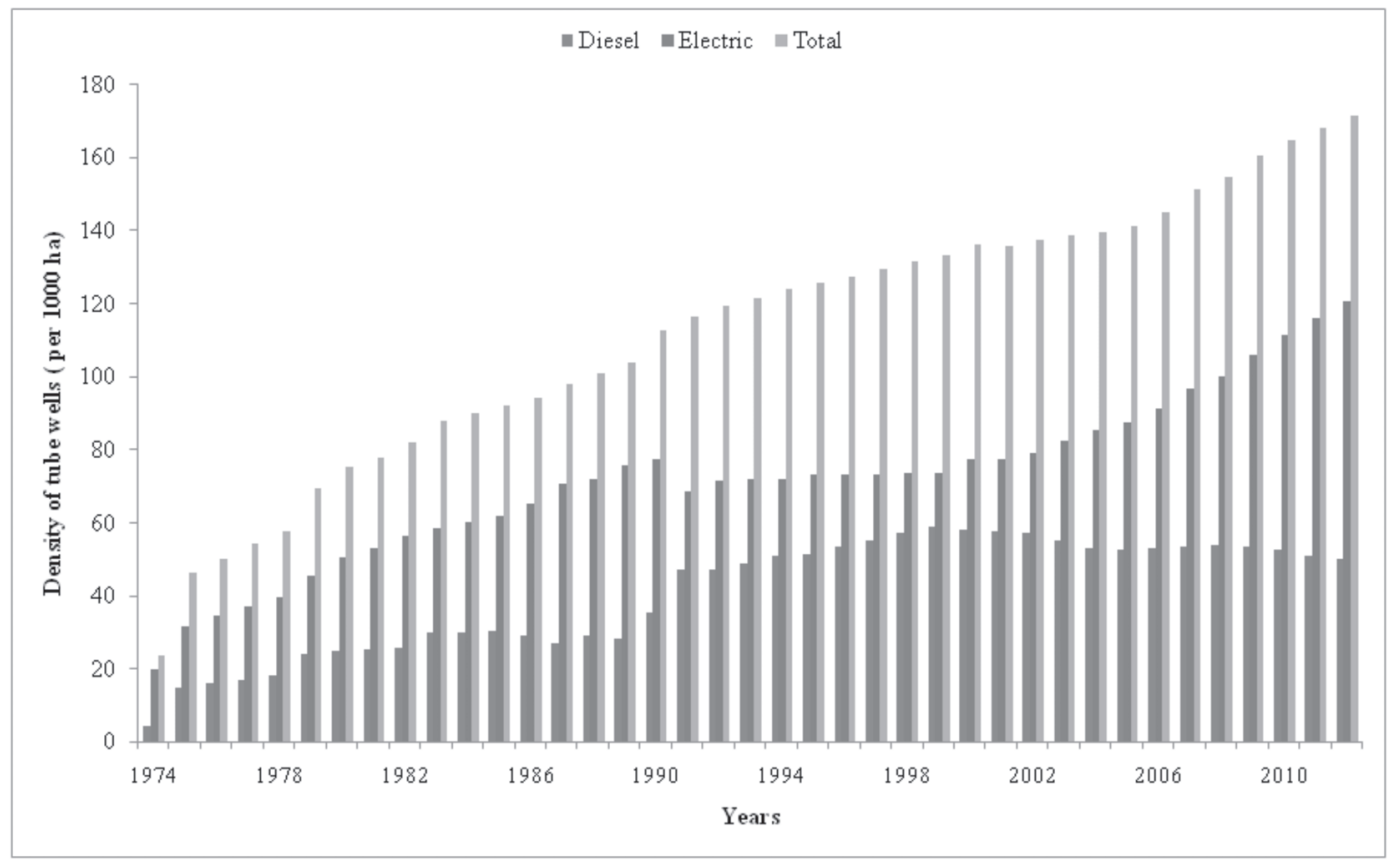

Amongst the three regions, semi-arid region had thehighest tubewell density including diesel and electric tube wells (Table 1). Interestingly, though the overall density of tube wells in the State has increased, the density of diesel-operated tube wells has decreased on account of high operation and maintenance cost except in the groundwater scarce arid region. An increase in the density of diesel tube wells in ground water scarce arid region of the State can be attributed to installation of these tube wells along the canals on account of fresh water availability at shallow depths. Besides, the cropping pattern of the region (bajra, jawar, cotton, mustard) demands less water and electric tube wells are considered to be more expensive to install as compared to diesel tube wells. These results show a clear paradoxical divide that water abundant regions in the country are saddled with diesel tube wells, while water scarce regions are well endowed with electric tube wells (Shah et al., 2006; Mukherji, 2007, 2008). 
Table 1: Density of Diesel and Electric Tube Wells (Per thousand hectares) in Haryana During 2008-09 and 2012-13

\begin{tabular}{|c|c|c|c|c|c|c|}
\hline \multirow[t]{2}{*}{ District } & \multicolumn{3}{|c|}{$2008-09$} & \multicolumn{3}{|c|}{$2012-13$} \\
\hline & Diesel & Electric & Total & Diesel & Electric & Total \\
\hline \multicolumn{7}{|c|}{ Sub-Humid Region } \\
\hline Ambala & 30.5 & 120.2 & 150.6 & 31.0 & 145.6 & 176.6 \\
\hline Panchkula & 13.5 & 32.1 & 45.6 & 13.6 & 40.5 & 54.2 \\
\hline Yamunanagar & 48.8 & 127.4 & 176.3 & 32.8 & 151.5 & 184.3 \\
\hline Sub-humid region & 34.5 & 104.5 & 139.1 & 28.1 & 125.8 & 153.9 \\
\hline \multicolumn{7}{|c|}{ Semi-Arid Region } \\
\hline Faridabad & 38.2 & 94.2 & 132.4 & 31.3 & 111.3 & 142.6 \\
\hline Gurgaon & 5.9 & 176.5 & 182.4 & 4.7 & 205.9 & 210.6 \\
\hline J hajjar & 185.7 & 35.2 & 220.9 & 115.7 & 41.4 & 157.1 \\
\hline Kaithal & 90.9 & 155.9 & 246.8 & 81.7 & 190.8 & 272.5 \\
\hline Karnal & 38.0 & 229.6 & 267.6 & 0.7 & 172.3 & 173.0 \\
\hline Kurukshetra & 1.3 & 244.2 & 245.5 & 58.3 & 442.0 & 500.3 \\
\hline Mewat & 43.0 & 45.2 & 88.1 & 50.7 & 54.8 & 105.4 \\
\hline Palwal & 119.9 & 59.9 & 179.7 & 109.3 & 75.9 & 185.3 \\
\hline Panipat & 29.3 & 211.7 & 241.0 & 22.8 & 246.4 & 269.2 \\
\hline Rewari & 18.7 & 162.2 & 180.8 & 32.9 & 190.1 & 223.0 \\
\hline Rohtak & 97.1 & 17.8 & 114.9 & 90.4 & 21.1 & 111.6 \\
\hline Sonipat & 105.2 & 95.4 & 200.6 & 98.1 & 114.2 & 212.2 \\
\hline Semi-arid region & 69.3 & 130.3 & 199.6 & 60.3 & 154.1 & 214.4 \\
\hline \multicolumn{7}{|c|}{ Arid Region } \\
\hline Bhiwani & 25.3 & 50.8 & 76.1 & 46.9 & 62.5 & 109.4 \\
\hline Fatehabad & 37.4 & 98.5 & 135.9 & 34.5 & 122.8 & 157.3 \\
\hline Hisar & 52.7 & 20.6 & 73.3 & 49.1 & 28.7 & 77.8 \\
\hline Jind & 74.8 & 94.5 & 169.3 & 69.7 & 121.7 & 191.4 \\
\hline Mahendergarh & 0.8 & 134.1 & 134.9 & 0.7 & 155.3 & 156.0 \\
\hline Sirsa & 52.1 & 71.2 & 123.3 & 44.6 & 91.5 & 136.1 \\
\hline Arid region & 42.2 & 68.8 & 111.1 & 44.0 & 86.2 & 130.2 \\
\hline Haryana & 53.6 & 99.8 & 153.4 & 49.8 & 120.4 & 170.2 \\
\hline
\end{tabular}

Source: Compiled by authors.

District-wise analysis revealed that Kurukshetra district in semi-arid region and Bhiwani district in arid region have witnessed the largest percentage increase in density of tube wellswith Kurukshetra recording over 80 percent increase in electric tube wells and Bhiwani with an increase of more than 40 per cent in diesel tube wells during 2008-09 and 2012-13. Growth rates in density of tube wells have, however, declined in Karnal, J hajjar and Rohtak districts. Negative growth in Karnal district can be attributed to shifting of shallow tube wellsto deep tube wells (submersible tube wells), while in Rohtak and J hajjar,the same may be ascribed to poor quality of groundwater. Kurukshetra district has maintained its lead in the State with the most 
number of tube wells since 1974-75. The number of tube wells here has grown the fastest with no sign of slowing down and as of today, the district farmers have about 10 per cent of all tube wells in Haryana.

Source of Financing of Tube Wells: Tube well installation depends upon the income source of farmers. Haryana's rural credit markets are characterised by co-existence of formal, semiformal and informal lenders like any other part of the country. Table 2 shows that about 20-35 per cent of farmersuse their own funds for installation of tube wells. Financial institutions such as commercial and co-operative banks have emerged as the most important sources of finance for farmers in Haryana. However, it is indeed a matter of concern that in spite of all the efforts made for their development, institutional finance accounts for about 15 per cent of the total loans disbursed for tube well installation. Meanwhile, commission agents, moneylenders and traders are still contributing for more than 50 per cent of the total credit for tube well installations (Table 2). Other non-institutional sources such as friends and relatives account for about 10 per cent of the credit providers for installation of tube wells in the State.

Table 2: Sources of Financing for Tube Wells in Haryana

\begin{tabular}{|lcccc|}
\hline Farmer Class & $\begin{array}{c}\text { Own Saving } \\
(\%)\end{array}$ & $\begin{array}{c}\text { Commercial and } \\
\text { Co-operative } \\
\text { Banks } \\
(\%)\end{array}$ & $\begin{array}{c}\text { Commission } \\
\text { Agentsand } \\
\text { Moneylenders } \\
(\%)\end{array}$ & $\begin{array}{c}\text { Relatives, } \\
\text { Friendsand } \\
\text { Others } \\
(\%)\end{array}$ \\
\hline Small & 19.9 & 5.2 & 61.8 & 13.1 \\
Medium & 30.5 & 15.3 & 49.6 & 4.5 \\
Large & 33.8 & 15.7 & 40.8 & 9.8 \\
\hline
\end{tabular}

Source: Field survey by authors.

Groundwater Irrigation-Energy Nexus: Groundwaterirrigation useshigh capacity electric and diesel tubewells.Therefore, energy subsidies are another key area in groundwater economy of Haryana. Agricultural tube well users have to pay only a small fraction of actual tariff,resulting in large quantum of subsidies, thousandsto crores of rupees,for irrigation sector. Therefore,farmers are turning more and more towards installation of electric tube wells (Figure 3). A direct consequence of this surge in electric tube wells has been mounting perpetual loss and poor financial health to the State. The gross subsidy provided to tube well users and subsequently normalised by using the State's gross cropped area in recent years has been highlighted in Table 3. Meanwhile, electricity subsidies to electric tube wells have led to indiscriminate use of groundwater for irrigation, resulting in severe depletion of groundwater levels. During theyear 2012-13, more than two-thirds of groundwater depth monitoring wells reported depths greater than five metres and about 62.5 per cent of wells recorded a fall in groundwater levels from the previous year (CGWB, 2013). 
Table 3: Electricity Subsidies to Tube Well Users in Haryana

\begin{tabular}{|lccc|}
\hline Year & $\begin{array}{c}\text { Aggregate Subsidy to } \\
\text { TubeWell Users } \\
\text { (Billion ₹) }\end{array}$ & $\begin{array}{c}\text { Normalised Electricity } \\
\text { Subsidies to TubeWell } \\
\text { Users (₹/ha) }\end{array}$ & $\begin{array}{c}\text { Subsidies to TubeWell } \\
\text { Users (Percentage } \\
\text { of the total subsidies } \\
\text { available to farmers) }\end{array}$ \\
\hline $2010-11$ & 34.35 & 5373 & 45 \\
$2011-12$ & 34.21 & 5366 & 43 \\
$2012-13$ & 39.74 & 6234 & 44 \\
$2013-14$ & 48.53 & 7613 & 51 \\
\hline
\end{tabular}

Source: Sharma et al., 2015.

Spread of Hired and Own Irrigated Area through Tube Wells: Spread of hired and own irrigated area through tube wells in the State of Haryana has been presented in Table 4. About 6.9 per cent area wasirrigated through hired tube wells during 2008-09, whereas it has increased to 7.3 per cent during the year 2012-13, thus indicating that area underhired irrigation through tube wells is increasing. However, area irrigated through hired tube wells in the State is comparatively low. The net irrigated area from all sources in the State was about 2.8 million ha during the year 2008-09, out of this 1.2 million ha was irrigated through surface water (canal), while the rest 1.6 million ha was irrigated by utilising the groundwater resources. During the year 2012-13, net irrigated area in the State was observed to be 3.0 million ha, out of which 1.3 million ha was irrigated through surface water and 1.7 million ha through groundwater resource. It shows a growth of 10 per cent in utilisation of groundwater for irrigation from 2008-09 to 2012-13.

Table 4: Net Area Irrigated through Hired Tube Wells, Own Tube Wells and Percentage of Households Reporting Irrigation from Hired Tube Wells in Haryana During 2008-09 and 2012-13

\begin{tabular}{|c|c|c|c|c|c|c|}
\hline District & & 2008-09 & & & $2012-13$ & \\
\hline & $\begin{array}{l}\text { Net Area } \\
\text { Irrigated } \\
\text { through } \\
\text { Hired Tube } \\
\text { Wells (\%) }\end{array}$ & $\begin{array}{l}\text { Net Area } \\
\text { Irrigated } \\
\text { through } \\
\text { Own Tube } \\
\text { Wells (\%) }\end{array}$ & $\begin{array}{l}\text { Households } \\
\text { Reporting } \\
\text { Irrigation } \\
\text { through } \\
\text { Hired Tube } \\
\text { Wells (\%) }\end{array}$ & $\begin{array}{l}\text { Net Area } \\
\text { Irrigated } \\
\text { through } \\
\text { Hired Tube } \\
\text { Wells (\%) }\end{array}$ & $\begin{array}{l}\text { Net Area } \\
\text { Irrigated } \\
\text { through } \\
\text { Own Tube } \\
\text { Wells (\%) }\end{array}$ & $\begin{array}{c}\text { Households } \\
\text { Reporting } \\
\text { Irrigation } \\
\text { through } \\
\text { Hired Tube } \\
\text { Wells (\%) }\end{array}$ \\
\hline 1 & 2 & 3 & 4 & 5 & 6 & 7 \\
\hline \multicolumn{7}{|c|}{ Sub-Humid Region } \\
\hline Ambala & 11.5 & 88.5 & 30.6 & 17.6 & 82.4 & 37.1 \\
\hline Panchkula & NA & NA & NA & NA & NA & NA \\
\hline Yamunanagar & 2.5 & 97.5 & 15.0 & 0.0 & 100.0 & 0.0 \\
\hline
\end{tabular}


Table 4 (Contd.....)

\begin{tabular}{|c|c|c|c|c|c|c|}
\hline 1 & 2 & 3 & 4 & 5 & 6 & 7 \\
\hline Sub-humid region & 8.6 & 91.4 & 27.2 & 7.9 & 92.1 & 17.1 \\
\hline \multicolumn{7}{|c|}{ Semi-Arid Region } \\
\hline Faridabad & 0.0 & 100.0 & 0.0 & 7.2 & 92.8 & 16.7 \\
\hline Gurgaon & 2.2 & 97.8 & 0.0 & 12.3 & 87.7 & 13.2 \\
\hline Jhajjar & 0.0 & 100.0 & 0.0 & 8.8 & 91.2 & 7.1 \\
\hline Kaithal & 0.0 & 100.0 & 0.0 & 0.0 & 100.0 & 0.0 \\
\hline Karnal & 0.0 & 100.0 & 0.0 & 0.0 & 100.0 & 0.0 \\
\hline Kurukshetra & 0.0 & 100.0 & 0.0 & 0.0 & 100.0 & 0.0 \\
\hline Mewat & NA & NA & NA & NA & NA & NA \\
\hline Palwal & NA & NA & NA & NA & NA & NA \\
\hline Panipat & 0.0 & 100.0 & 0.0 & 0.0 & 100.0 & 0.0 \\
\hline Rohtak & 16.4 & 83.6 & 7.0 & 0.0 & 100.0 & 0.0 \\
\hline Rewari & 8.0 & 92.0 & 10.5 & 10.5 & 89.5 & 11.5 \\
\hline Sonipat & 1.7 & 98.3 & 0.0 & 0.0 & 100.0 & 0.0 \\
\hline Semi-arid region & 2.2 & 97.8 & 2.4 & 2.5 & 97.5 & 4.6 \\
\hline \multicolumn{7}{|c|}{ Arid Region } \\
\hline Bhiwani & 5.1 & 94.9 & 6.3 & 7.0 & 93.0 & 9.4 \\
\hline Fatehabad & 15.1 & 84.9 & 25.7 & 14.0 & 86.0 & 20.0 \\
\hline Hisar & 15.1 & 84.9 & 13.4 & 19.3 & 80.7 & 21.9 \\
\hline Jind & 4.4 & 95.6 & 11.8 & 10.5 & 89.5 & 11.1 \\
\hline Mahendergarh & 0.0 & 100.0 & 0.0 & NA & NA & NA \\
\hline Sirsa & 18.6 & 81.4 & 32.7 & 22.3 & 77.7 & 31.8 \\
\hline Arid region & 11.7 & 88.3 & 15.2 & 13.9 & 86.1 & 17.5 \\
\hline Haryana & 6.9 & 93.1 & 10.6 & 7.3 & 92.7 & 10.8 \\
\hline
\end{tabular}

Source: Compiled by authors.

NA: Data not available.

There are marked inter-regional differences in areaand percentage of households irrigating their fields through hired tube wells (Table 4, Figure 5). Arid region has the highest area under hired tube well irrigation, while the semi-arid region exhibited underdeveloped groundwater markets in spite of fresh water availability and large number of tube wells. Both high water demand and economic returns from the cultivation of rice crop compelled thefarmers to invest in their own tubewells. Apart from this, about 11 percent of households in the State are dependent on hired irrigation through tube wells, highest being in sub-humid region followed by arid. Higher dependence on hired irrigation through tube wells in sub-humid region can be attributed to larger proportion of fragmented land holdings and farmers cannot afford installation of tube wells. 
Figure 5: Percentage of Households Reported Irrigation from Hired and Own Tube Wells During 2008-09 and 2012-13

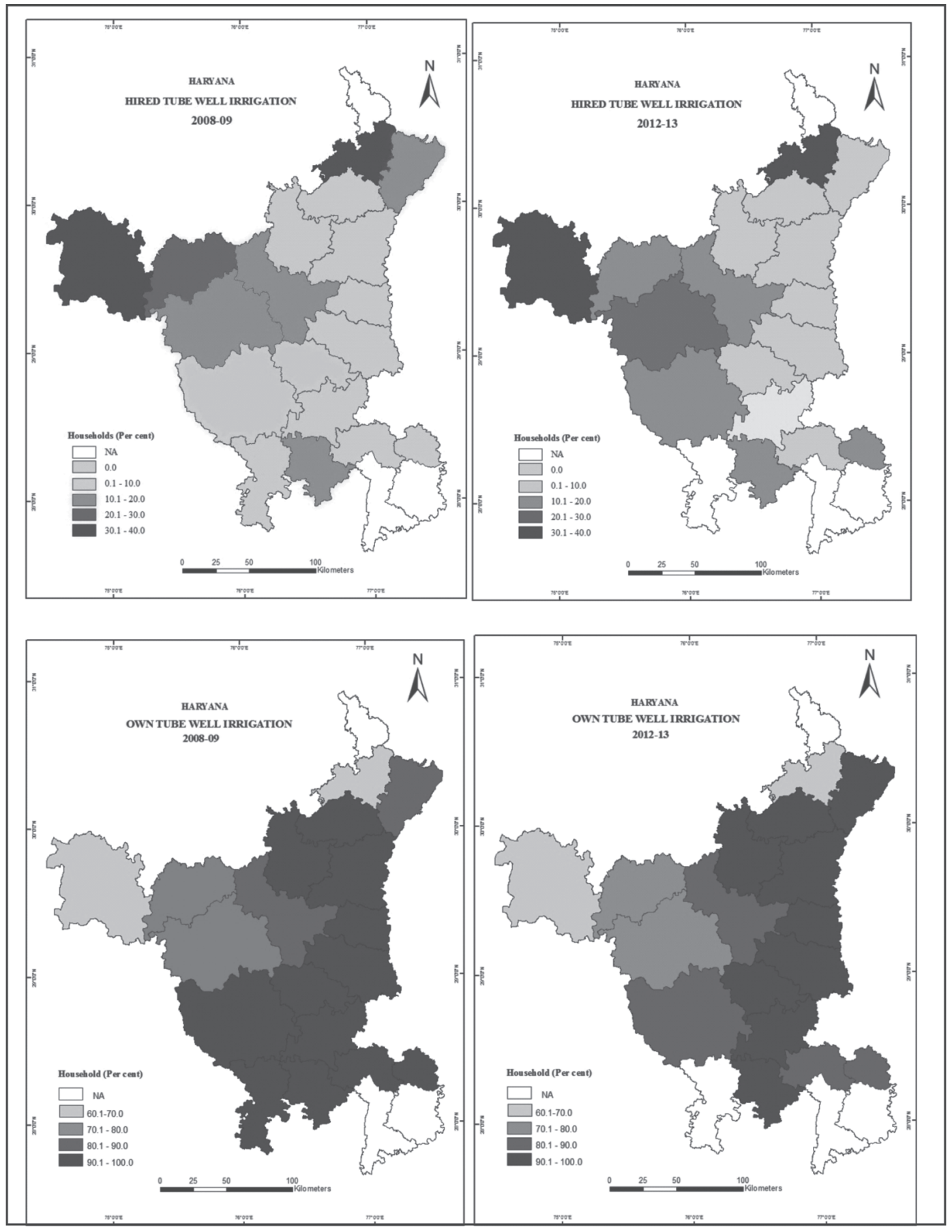

Journal of Rural Development, Vol. 36, No. 4, October-December : 2017 
Hired and Own Irrigated Area through Tube Wells during Rabi and Kharif Seasons: Wheat, mustard (rabi), rice and cotton (kharif) are the major irrigated crops in Haryana and optimise the economic returns of cultivators. During the study period, hired irrigated area through tube wells has increased under mustard and cotton crops, while it has decreased under wheat and rice crops across the State (Tables 5 and 6). Higher irrigated area through groundwater markets under mustard and cotton crops can be anomalously attributed to remunerative prices of these cropsduring the study period. Moreover, percentage of households reporting wheat and cotton irrigation through hired tube wells has increased, whereas the same has decreased under mustard and rice crops. A decrease in percentage of householdsreporting rice irrigation through hired tube wells can be attributed to higher water demand of the crop which compelled the farmers to install their own tube wells, whereas this decrease under cotton crop is beyond understanding. Amongst the regions, arid region registered an increase of hired irrigated area through tube wellsunder all crops except the mustard. Meanwhile, percentage of households reporting irrigation through hired tube wells under all crops peaked in Ambala district of the State (Figure 6) whereas, Kaithal, Karnal and Kurukshetra districtshad not witnessed hired irrigation through tube wellsunder all crops, supporting the fact that these districts have consistently maintained a very high tube well density in the State (Table 1).

\section{Figure 6: Percentage of Households Reported Irrigation in Wheat Crop from Hired and} Own Tube Wells During 2008-09 and 2012-13

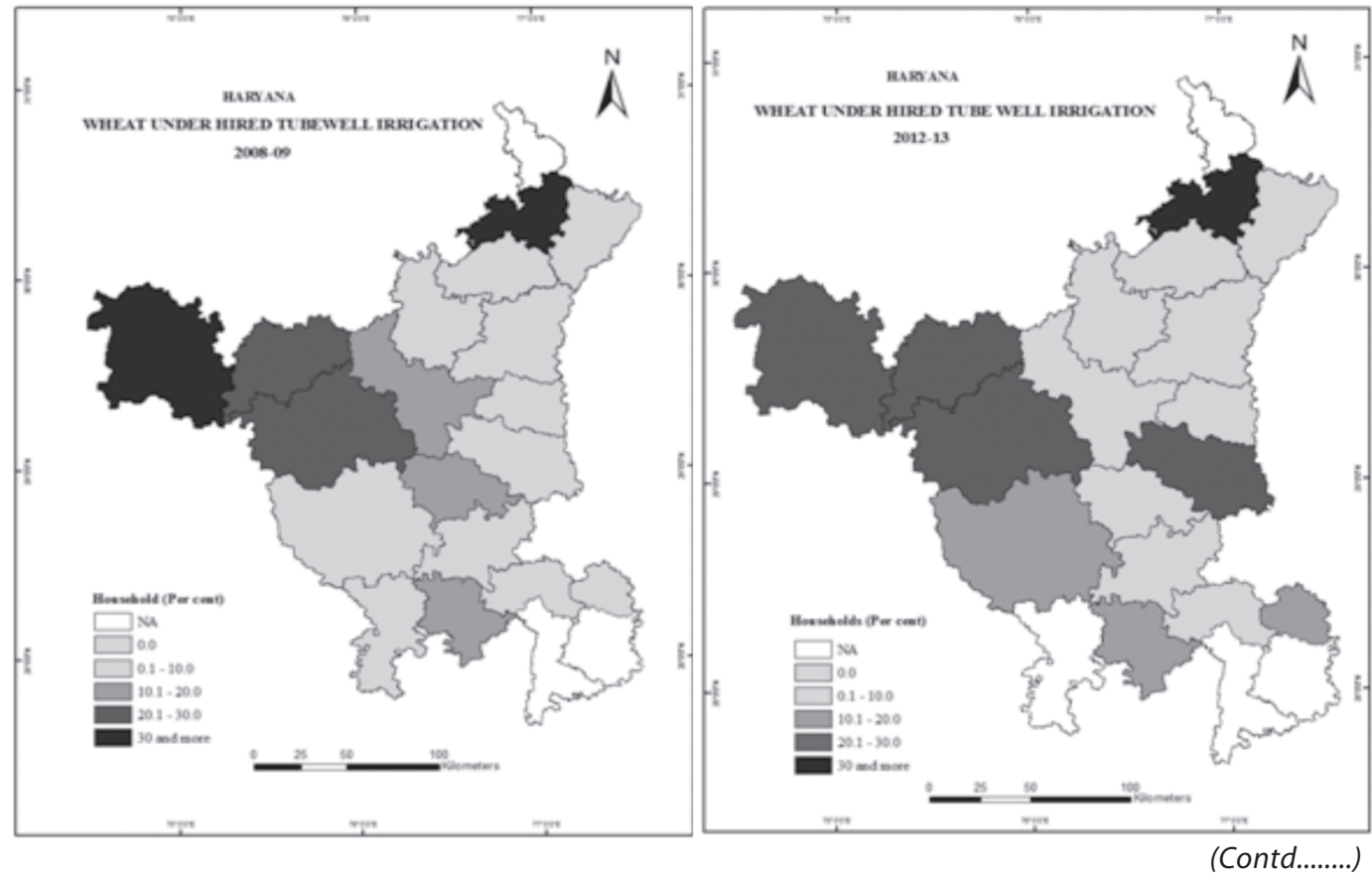

Journal of Rural Development, Vol. 36, No. 4, October-December : 2017 
Figure 6 (Contd.....)

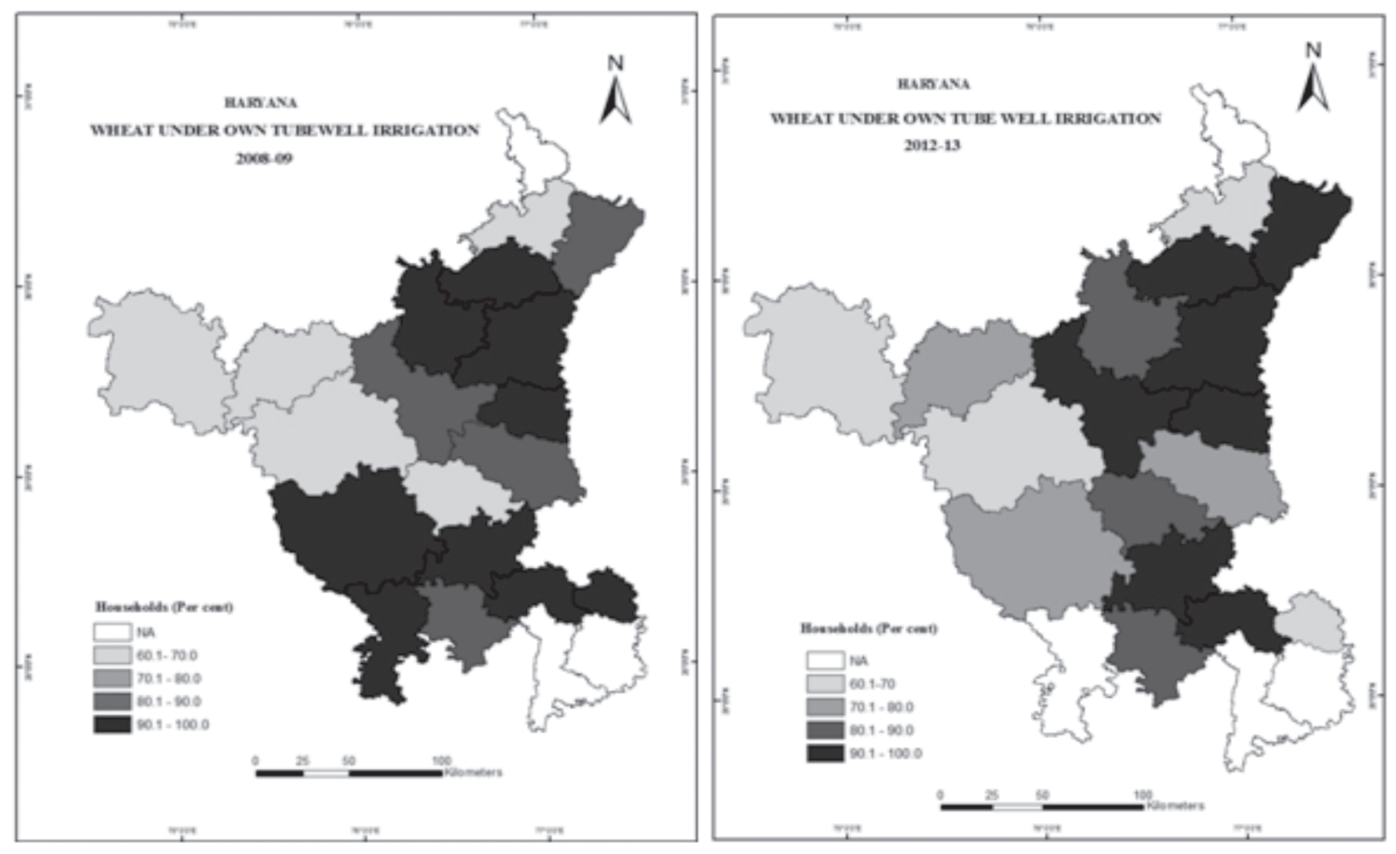

Table 5: Net Area Irrigated through Hired Tube Wells, Own Tube Wells and Percentage of Households Reporting Irrigation from Hired Tube Wells in Haryana under Wheat and Mustard Crops During Rabi Season for the Period 2008-09 and 2012-13

\begin{tabular}{|c|c|c|c|c|c|c|}
\hline \multirow[t]{2}{*}{ District } & \multicolumn{3}{|c|}{ 2008-09 } & \multicolumn{3}{|c|}{ 2012-13 } \\
\hline & $\begin{array}{l}\text { Net Area } \\
\text { Irrigated } \\
\text { through } \\
\text { Hired Tube } \\
\text { Wells (\%) }\end{array}$ & $\begin{array}{l}\text { Net Area } \\
\text { Irrigated } \\
\text { through } \\
\text { Own Tube } \\
\text { Wells (\%) }\end{array}$ & $\begin{array}{l}\text { Households } \\
\text { Reporting } \\
\text { Irrigation } \\
\text { through } \\
\text { Hired Tube } \\
\text { Wells (\%) }\end{array}$ & $\begin{array}{l}\text { Net area } \\
\text { Irrigated } \\
\text { through } \\
\text { Hired Tube } \\
\text { Wells (\%) }\end{array}$ & $\begin{array}{l}\text { Net Area } \\
\text { Irrigated } \\
\text { through } \\
\text { Own Tube } \\
\text { Wells (\%) }\end{array}$ & $\begin{array}{l}\text { Households } \\
\text { Reporting } \\
\text { Irrigation } \\
\text { through } \\
\text { Hired Tube } \\
\text { Wells (\%) }\end{array}$ \\
\hline 1 & 2 & 3 & 4 & 5 & 6 & 7 \\
\hline \multicolumn{7}{|c|}{ Wheat Crop } \\
\hline $\begin{array}{l}\text { Sub-Humid Region } \\
\text { Ambala }\end{array}$ & 15.1 & 84.9 & 34.4 & 22.0 & 78.0 & 47.1 \\
\hline Panchkula & NA & NA & NA & NA & NA & NA \\
\hline Yamunanagar & 1.1 & 98.9 & 10.0 & 0.0 & 100.0 & 0.0 \\
\hline Sub-humid region & 9.9 & 90.1 & 28.6 & 11.5 & 88.5 & 27.6 \\
\hline \multicolumn{7}{|c|}{ Semi-Arid Region } \\
\hline Faridabad & 0.0 & 100.0 & 0.0 & 8.2 & 91.8 & 18.5 \\
\hline Gurgaon & 0.0 & 100.0 & 0.0 & 6.1 & 93.9 & 11.8 \\
\hline
\end{tabular}

(Contd.........) 
Table 5 (Contd.....)

\begin{tabular}{|c|c|c|c|c|c|c|}
\hline 1 & 2 & 3 & 4 & 5 & 6 & 7 \\
\hline Jhajjar & 0.0 & 100.0 & 0.0 & 0.0 & 100.0 & 0.0 \\
\hline Kaithal & 0.0 & 100.0 & 0.0 & 0.0 & 100.0 & 0.0 \\
\hline Karnal & 0.0 & 100.0 & 0.0 & 0.0 & 100.0 & 0.0 \\
\hline Kurukshetra & 0.0 & 100.0 & 0.0 & 0.0 & 100.0 & 0.0 \\
\hline Mewat & NA & NA & NA & NA & NA & NA \\
\hline Palwal & NA & NA & NA & NA & NA & NA \\
\hline Panipat & 4.8 & 95.2 & 0.0 & 0.0 & 100.0 & 0.0 \\
\hline Rewari & 20.5 & 79.5 & 16.0 & 7.6 & 92.4 & 15.8 \\
\hline Rohtak & 14.3 & 85.7 & 16.7 & 0.0 & 100.0 & 0.0 \\
\hline Sonipat & 3.9 & 96.1 & 3.0 & 0.0 & 100.0 & 0.0 \\
\hline Semi-arid region & 4.8 & 95.2 & 3.3 & 1.3 & 98.7 & 4.6 \\
\hline \multicolumn{7}{|c|}{ Arid Region } \\
\hline Bhiwani & 1.7 & 98.3 & 5.3 & 6.3 & 93.7 & 18.5 \\
\hline Fatehabad & 13.7 & 86.3 & 26.3 & 18.3 & 81.7 & 28.5 \\
\hline Hisar & 13.9 & 86.1 & 27.6 & 23.1 & 76.9 & 13.6 \\
\hline Jind & 6.0 & 94.0 & 16.7 & 3.0 & 97.0 & 6.7 \\
\hline Mahendergarh & 0.0 & 100.0 & 0.0 & NA & NA & NA \\
\hline Sirsa & 19.5 & 80.5 & 37.0 & 26.8 & 73.2 & 14.3 \\
\hline Arid region & 11.5 & 88.5 & 20.8 & 14.3 & 85.7 & 18.3 \\
\hline Haryana & 7.4 & 92.6 & 12.6 & 6.9 & 93.1 & 17.6 \\
\hline \multicolumn{7}{|c|}{$\begin{array}{l}\text { Mustard Crop } \\
\text { Semi-Arid Region }\end{array}$} \\
\hline Gurgaon & 9.8 & 90.2 & 27.3 & 20.8 & 79.2 & 36.4 \\
\hline Jhajjar & 0.0 & 100.0 & 0.0 & 17.3 & 82.7 & 17.2 \\
\hline Rewari & 10.7 & 89.3 & 16.0 & 11.8 & 88.2 & 16.7 \\
\hline Rohtak & 27.6 & 72.4 & 14.3 & 0.0 & 100.0 & 0.0 \\
\hline Sonipat & 0.0 & 0.0 & 0.0 & 0.0 & 100.0 & 0.0 \\
\hline Semi-arid region & 11.4 & 88.6 & 16.7 & 14.4 & 85.6 & 16.1 \\
\hline \multicolumn{7}{|c|}{ Arid Region } \\
\hline Bhiwani & 18.8 & 81.3 & 18.5 & 8.4 & 91.6 & 15.4 \\
\hline Fatehabad & 100.0 & 0.0 & 66.7 & 0.0 & 100.0 & 0.0 \\
\hline Hisar & 10.5 & 89.5 & 13.6 & 18.3 & 81.7 & 21.9 \\
\hline Jind & 0.0 & 0.0 & 0.0 & 0.0 & 100.0 & 27.3 \\
\hline Mahendergarh & 0.0 & 100.0 & 0.0 & NA & NA & NA \\
\hline Sirsa & 0.0 & 100.0 & 14.3 & 0.0 & 100.0 & 0.0 \\
\hline Arid region & 13.3 & 86.7 & 18.3 & 11.4 & 88.6 & 18.7 \\
\hline Haryana & 12.4 & 87.6 & 17.6 & 12.9 & 87.1 & 17.0 \\
\hline
\end{tabular}

Source: Compiled by authors. NA: Data not available.

Journal of Rural Development, Vol. 36, No. 4, October-December : 2017 
Table 6: Net Area Irrigated through Hired Tube Wells, Own Tube Wells and Percentage of Households Reporting Irrigation from Hired Tube Wells in Haryana under Rice and Cotton Crops During Kharif Season for the Period 2008-09 and 2012-13

\begin{tabular}{|c|c|c|c|c|c|c|}
\hline \multirow[t]{6}{*}{ District } & \multicolumn{3}{|c|}{ 2008-09 } & \multicolumn{3}{|c|}{$2012-13$} \\
\hline & Net Area & Net Area & Households & Net Area & Net Area & Households \\
\hline & Irrigated & Irrigated & Reporting & Irrigated & Irrigated & Reporting \\
\hline & through & through & Irrigation & through & through & Irrigation \\
\hline & Hired Tube & OwnTube & through & Hired Tube & Own Tube & through \\
\hline & Wells (\%) & Wells (\%) & $\begin{array}{l}\text { Hired Tube } \\
\text { Wells (\%) }\end{array}$ & Wells (\%) & Wells (\%) & $\begin{array}{l}\text { Hired Tube } \\
\text { Wells (\%) }\end{array}$ \\
\hline 1 & 2 & 3 & 4 & 5 & 6 & 7 \\
\hline \multicolumn{7}{|c|}{$\begin{array}{c}\text { Rice Crop } \\
\text { Sub-Humid Region }\end{array}$} \\
\hline Ambala & 8.0 & 92.0 & 32.3 & 10.8 & 89.2 & 25.0 \\
\hline Yamunanagar & 4.2 & 95.8 & 20.0 & 0.0 & 100.0 & 0.0 \\
\hline Sub-humid region & 6.8 & 93.2 & 29.3 & 5.0 & 95.0 & 11.5 \\
\hline \multicolumn{7}{|c|}{ Semi-Arid Region } \\
\hline Faridabad & 0.0 & 100.0 & 0.0 & 11.8 & 88.2 & 22.2 \\
\hline Gurgaon & 0.0 & 100.0 & 0.0 & 0.0 & 100.0 & 0.0 \\
\hline Jhajjar & 0.0 & 100.0 & 0.0 & 0.0 & 100.0 & 0.0 \\
\hline Kaithal & 0.0 & 100.0 & 0.0 & 0.0 & 100.0 & 0.0 \\
\hline Karnal & 0.0 & 100.0 & 0.0 & 0.0 & 100.0 & 0.0 \\
\hline Kurukshetra & 0.0 & 100.0 & 0.0 & 0.0 & 100.0 & 0.0 \\
\hline Panipat & 0.0 & 100.0 & 0.0 & 0.0 & 100.0 & 0.0 \\
\hline Rewari & 0.0 & 0.0 & 0.0 & 0.0 & 100.0 & 0.0 \\
\hline Rohtak & 0.0 & 100.0 & 0.0 & 0.0 & 100.0 & 0.0 \\
\hline Sonipat & 2.7 & 97.3 & 8.3 & 0.0 & 100.0 & 0.0 \\
\hline Semi-arid region & 0.4 & 99.6 & 0.9 & 0.3 & 99.7 & 1.6 \\
\hline \multicolumn{7}{|c|}{ Arid Region } \\
\hline Bhiwani & 0.0 & 100.0 & 0.0 & 0.0 & 100.0 & 0.0 \\
\hline Fatehabad & 3.1 & 96.9 & 4.3 & 3.0 & 97.0 & 8.3 \\
\hline Hisar & 0.0 & 100.0 & 0.0 & 0.0 & 100.0 & 0.0 \\
\hline Jind & 1.8 & 98.2 & 10.0 & 6.5 & 93.5 & 8.7 \\
\hline Sirsa & 0.0 & 0.0 & 0.0 & 0.0 & 100.0 & 0.0 \\
\hline Arid region & 2.5 & 97.5 & 5.3 & 5.1 & 94.9 & 8.3 \\
\hline Haryana & 2.3 & 97.7 & 7.9 & 1.7 & 98.3 & 5.4 \\
\hline \multicolumn{7}{|c|}{$\begin{array}{l}\text { Cotton Crop } \\
\text { Arid Region }\end{array}$} \\
\hline Bhiwani & 4.0 & 96.0 & 6.7 & 6.4 & 93.6 & 12.0 \\
\hline Fatehabad & 24.7 & 75.3 & 38.5 & 22.3 & 77.7 & 27.8 \\
\hline Hisar & 20.9 & 79.1 & 17.4 & 15.8 & 84.2 & 20.4 \\
\hline Jind & 10.5 & 89.5 & 20.0 & 23.3 & 76.7 & 15.4 \\
\hline Sirsa & 17.9 & 82.1 & 28.6 & 22.4 & 77.6 & 40.0 \\
\hline Arid region & 17.7 & 82.3 & 21.9 & 17.8 & 82.2 & 20.3 \\
\hline Haryana & 16.9 & 83.1 & 20.0 & 17.8 & 82.2 & 20.3 \\
\hline
\end{tabular}

Source: Compiled by authors.

NA: Data not available.

Journal of Rural Development, Vol. 36, No. 4, October-December : 2017 
Yield of Hired and Own Irrigated Crops through Tube Wells: Irrigation is an essential demand of crop on which the yield depends and it is expected that with increased number of irrigations, the crops are also likely to give higher yields. However, yield of crops is dependent on several other factors such as, quantity of inputs applied in the production cycle (high-yielding variety seeds, fertilisers, etc.) including the institutional framework, soil and climatic conditions, cropping patterns and water conveyance infrastructure (Bjornlund et al., 2007). Apart from these, farmers who own tube wells can supply water at requirement of the crop, whereas the buyer relies upon the seller for availability of water,resulting in more yieldsfor a particular crop to those farmers who own a tube well. It can be witnessed from Tables 7 and 8 that yield of wheat and rice crops was more in the State of Haryana through the irrigation of own tubewells as they applied more amount of water than the farmers irrigating these crops through hired tube wells. However, such results in the case of mustard crop yield could not be observed, while a noticeable higher yield was observed in cotton crop for the farmers irrigating through hired tube wells. The high yield in the case of hired irrigation under cotton crop could be due to the fact that the farmers irrigating cotton through hired tube wells apply less amount of water as compared to the farmers irrigating through own tube wells, since root system of the cotton crop is very sensitive to the excess irrigation. Also, more than 80 per cent farmers having their own tube wells in the State preferred cotton crop on account of higher productivity, yields and subsequently,thenet returns in relation to other crops. Likewise, marked inter-regional differences in yield of different crops were noticed. Sub-humid region recorded highest yield in rice crop followed by arid and semi-arid regions, while highest wheat yield was noticed in semi-arid region followed by arid region. Furthermore, Fatehabad district recorded highest yield in rice crop followed by Ambala and Sirsa districts. Yamunanagar district witnessed the highestyield of wheat crop followed by Gurgaon and Kaithal districts. In addition, Gurgaon district recorded highest yield of mustard crop, while Bhiwani district experienced highest yield of cotton crop during 2008-09 and 2012-13 (Tables 7 and 8).

Table 7: Yield of Rabi Crops (tonnes/ha) Irrigated through Own and Hired Tube Wells in Haryana During 2008-09 and 2012-13

\begin{tabular}{|lcccc|}
\hline District & \multicolumn{2}{c|}{ 2012-13 } \\
\hline \multicolumn{1}{c}{ Own Tube wells } & Hired TubeWells & Own TubeWells & Hired TubeWells \\
\hline Wheat Crop & & & & \\
Sub-Humid Region & & & 3.5 & 3.4 \\
Ambala & 2.8 & 2.6 & NA & NA \\
Panchkula & NA & NA & 5.1 & 0.0 \\
Yamunanagar & 4.7 & 4.5 & 4.3 & 3.4 \\
Sub-humid region & 3.7 & 3.5 & & (Contd........)
\end{tabular}


Table 7 (Contd.....)

\begin{tabular}{|c|c|c|c|c|}
\hline & Own Tube Wells & Hired Tube Wells & Own TubeWells & Hired Tube Wells \\
\hline & & Semi-Arid Region & & \\
\hline Faridabad & 4.6 & 0.0 & 4.7 & 4.7 \\
\hline Gurgaon & 5.0 & 0.0 & 4.9 & 5.5 \\
\hline Jhajjar & 4.7 & 0.0 & 3.6 & 0.0 \\
\hline Kaithal & 5.0 & 0.0 & 4.6 & 0.0 \\
\hline Karnal & 4.7 & 0.0 & 4.8 & 0.0 \\
\hline Kurukshetra & 4.4 & 0.0 & 4.8 & 0.0 \\
\hline Mewat & NA & NA & NA & NA \\
\hline Palwal & NA & NA & NA & NA \\
\hline Panipat & 4.8 & 0.0 & 4.8 & 0.0 \\
\hline Rewari & 3.9 & 3.7 & 4.5 & 4.6 \\
\hline Rohtak & 4.6 & 4.4 & 3.6 & 0.0 \\
\hline Sonipat & 4.8 & 5.0 & 3.5 & 0.0 \\
\hline \multirow[t]{2}{*}{ Semi-arid region } & 4.7 & 4.4 & 4.4 & 4.9 \\
\hline & & Arid Region & & \\
\hline Bhiwani & 4.3 & 4.1 & 3.8 & 3.8 \\
\hline Fatehabad & 4.7 & 4.2 & 4.3 & 4.2 \\
\hline Hisar & 4.6 & 3.9 & 3.9 & 3.9 \\
\hline Jind & 4.8 & 4.5 & 4.4 & 4.7 \\
\hline Mahendergarh & 4.9 & 0.0 & NA & NA \\
\hline Sirsa & 4.3 & 4.6 & 4.6 & 4.7 \\
\hline Arid region & 4.6 & 4.3 & 4.2 & 4.2 \\
\hline \multirow[t]{3}{*}{ Haryana } & 4.3 & 4.0 & 4.3 & 4.2 \\
\hline & & Mustard Crop & & \\
\hline & & Semi-Arid Region & & \\
\hline Gurgaon & 2.0 & 2.1 & 2.1 & 2.0 \\
\hline Jhajjar & 1.6 & 0.0 & 1.4 & 1.2 \\
\hline Rewari & 1.9 & 1.5 & 2.0 & 2.0 \\
\hline Rohtak & 1.7 & 1.8 & 1.4 & 0.0 \\
\hline Sonipat & 0.0 & 0.0 & 1.7 & 0.0 \\
\hline \multirow[t]{2}{*}{ Semi-arid } & 1.8 & 1.8 & 1.7 & 1.7 \\
\hline & & Arid Region & & \\
\hline Bhiwani & 1.9 & 1.8 & 1.8 & 1.7 \\
\hline Fatehabad & 1.8 & 1.7 & 1.8 & 0.0 \\
\hline Hisar & 1.9 & 1.9 & 1.6 & 1.5 \\
\hline Jind & 0.0 & 0.0 & 1.7 & 0.0 \\
\hline Mahendergarh & 1.9 & 0.0 & 0.0 & 0.0 \\
\hline Sirsa & 1.6 & 1.5 & 1.5 & 0.0 \\
\hline Arid & 1.8 & 1.7 & 1.7 & 1.6 \\
\hline Haryana & 1.8 & 1.8 & 1.7 & 1.6 \\
\hline
\end{tabular}

Source: Compiled by authors.

NA: Data not available.

Journal of Rural Development, Vol. 36, No. 4, October-December : 2017 
Table 8: Yield of Kharif Crops (tonnes/ha) Irrigated through Own and Hired Tube Wells in Haryana During 2008-09 and 2012-13

\begin{tabular}{|c|c|c|c|c|}
\hline \multirow[t]{2}{*}{ District } & \multicolumn{2}{|c|}{ 2008-09 } & \multicolumn{2}{|c|}{$2012-13$} \\
\hline & Own TubeWells & Hired Tube Wells & Own TubeWells & Hired TubeWells \\
\hline \multicolumn{5}{|c|}{$\begin{array}{c}\text { Rice Crop } \\
\text { Sub-Humid Region }\end{array}$} \\
\hline Ambala & 5.4 & 4.8 & 6.1 & 5.2 \\
\hline Yamunanagar & 4.8 & 3.7 & 5.0 & 0.0 \\
\hline Sub-humid region & 5.1 & $\begin{array}{c}4.2 \\
\text { Semi-Arid Region }\end{array}$ & 5.5 & 5.2 \\
\hline Faridabad & 3.9 & 0.0 & 2.9 & 3.0 \\
\hline Gurgaon & 3.4 & 0.0 & 5.0 & 0.0 \\
\hline Jhajjar & 2.4 & 0.0 & 0.0 & 0.0 \\
\hline Kaithal & 3.5 & 0.0 & 6.0 & 0.0 \\
\hline Karnal & 3.3 & 0.0 & 5.4 & 0.0 \\
\hline Kurukshetra & 4.0 & 0.0 & 6.6 & 0.0 \\
\hline Panipat & 2.5 & 0.0 & 4.2 & 0.0 \\
\hline Rewari & 0.0 & 0.0 & 2.5 & 0.0 \\
\hline Rohtak & 4.6 & 0.0 & 3.7 & 0.0 \\
\hline Sonipat & 2.0 & 2.0 & 3.4 & 0.0 \\
\hline \multicolumn{5}{|c|}{ Arid Region } \\
\hline Bhiwani & 4.1 & 0.0 & 0.0 & 0.0 \\
\hline Fatehabad & 6.4 & 5.5 & 5.7 & 4.6 \\
\hline Hisar & 3.3 & 0.0 & 2.5 & 0.0 \\
\hline Jind & 3.5 & 3.0 & 6.0 & 5.4 \\
\hline Sirsa & 0.0 & 0.0 & 6.1 & 0.0 \\
\hline Arid region & 4.3 & 4.2 & 5.1 & 5.0 \\
\hline Haryana & 4.2 & 3.5 & 5.0 & 4.4 \\
\hline \multicolumn{5}{|c|}{ Cotton Crop Arid Region } \\
\hline Bhiwani & 2.1 & 3.0 & 1.9 & 2.6 \\
\hline Fatehabad & 2.0 & 2.2 & 2.1 & 2.1 \\
\hline Hisar & 2.1 & 1.4 & 1.8 & 1.6 \\
\hline Jind & 1.6 & 2.0 & 1.9 & 2.1 \\
\hline Sirsa & 2.2 & 1.8 & 2.0 & 2.5 \\
\hline Arid region & 2.0 & 2.1 & 1.9 & 2.2 \\
\hline
\end{tabular}

Source: Compiled by authors.

NA: Data not available.

Who Owns a Tube Well and Who Hires Groundwater?: Table 9 shows the distribution of tube well ownership among different landholding sizes of farmers in Haryana during
2008-09 and 2012-13. This shows that the bulk of tube wells are owned by small farmers followed by medium and large farmers. Tube well ownership pattern in the State has increased 
among small farmers, whereas it has decreased among large farmers and remained stagnant in medium farmers. A part from this, thereare interregional and inter-district variations in tube well ownership, but on the whole this pattern of small and marginal farmers overwhelmingly persisted across climatic regions and districts. Additionally, about 10 per cent farmers have relied on hired irrigation in Haryana through tube wells, out of which 90 per cent are small farmers (Tables 4 and 10).These results reveal that as the landholding size increases, more and more farmers depend on their own tube wells for irrigation.

Table 9: Distribution of Tube Well Ownership Among Farmers According to Operational Landholding Size Classes in Haryana During 2008-09 and 2012-13

\begin{tabular}{|c|c|c|c|c|c|c|}
\hline \multirow[t]{2}{*}{ District } & \multicolumn{3}{|c|}{ 2008-09 } & \multicolumn{3}{|c|}{$2012-13$} \\
\hline & Small & Medium & Large & Small & Medium & Large \\
\hline \multicolumn{7}{|c|}{ Sub-Humid Region } \\
\hline Ambala & 60.0 & 24.0 & 16.0 & 59.1 & 40.9 & 0 \\
\hline Panchkula & NA & NA & NA & NA & NA & NA \\
\hline Yamunanagar & 36.8 & 26.3 & 36.8 & 70.7 & 24.4 & 4.9 \\
\hline Sub-humid & 53.6 & 24.6 & 21.7 & 66.7 & 30.1 & 3.2 \\
\hline \multicolumn{7}{|c|}{ Semi-Arid Region } \\
\hline Faridabad & 53.3 & 40.0 & 6.7 & 76.2 & 19.0 & 4.8 \\
\hline Gurgaon & 79.4 & 20.6 & 0.0 & 91.7 & 4.2 & 4.2 \\
\hline Jhajjar & 89.5 & 10.5 & 0.0 & 83.6 & 9.8 & 6.6 \\
\hline Kaithal & 71.4 & 25.7 & 2.9 & 28.6 & 19.0 & 52.4 \\
\hline Karnal & 45.5 & 29.5 & 25.0 & 68.0 & 24.0 & 8.0 \\
\hline Kurukshetra & 41.7 & 33.3 & 25.0 & 51.9 & 30.8 & 17.3 \\
\hline Mewat & NA & NA & NA & NA & NA & NA \\
\hline Palwal & NA & NA & NA & NA & NA & NA \\
\hline Panipat & 71.4 & 28.6 & 0.0 & 39.1 & 47.8 & 13.0 \\
\hline Rewari & 88.1 & 11.9 & 0.0 & 71.8 & 25.6 & 2.6 \\
\hline Rohtak & 70.0 & 15.0 & 15.0 & 84.5 & 15.5 & 0.0 \\
\hline Sonipat & 57.8 & 37.8 & 4.4 & 66.7 & 28.3 & 5.0 \\
\hline Semi-arid & 69.1 & 24.2 & 6.7 & 69.4 & 21.8 & 8.8 \\
\hline \multicolumn{7}{|c|}{ Arid Region } \\
\hline Bhiwani & 90.7 & 9.3 & 0.0 & 76.9 & 15.4 & 7.7 \\
\hline Fatehabad & 54.1 & 23.0 & 23.0 & 64.7 & 25.5 & 9.8 \\
\hline Hisar & 70.0 & 22.5 & 7.5 & 69.6 & 28.3 & 2.2 \\
\hline Jind & 65.5 & 20.7 & 13.8 & 70.3 & 20.3 & 9.4 \\
\hline Mahendergarh & 68.4 & 31.6 & 0.0 & NA & NA & NA \\
\hline Sirsa & 51.5 & 42.4 & 6.1 & 50.0 & 31.3 & 18.8 \\
\hline Arid & 71.0 & 20.8 & 8.2 & 69.8 & 22.9 & 7.3 \\
\hline Haryana & 68.3 & 22.9 & 8.8 & 69.3 & 22.9 & 7.8 \\
\hline
\end{tabular}

Source: Compiled by authors.

NA: Data not available.

Journal of Rural Development, Vol. 36, No. 4, October-December : 2017 
Table 10: Number and Percentage of Households Hiring Irrigation from Tube Wells in Haryana During 2008-09 and 2012-13

\begin{tabular}{|lcccc|}
\hline Farmer Class & \multicolumn{2}{c}{$2008-09$} & \multicolumn{2}{c|}{$2012-13$} \\
\hline & $\begin{array}{c}\text { Number of } \\
\text { Householdswithin } \\
\text { the Operational } \\
\text { Landholding } \\
\text { Category Who } \\
\text { Reported Hiring } \\
\text { Irrigation from } \\
\text { TubeWells }\end{array}$ & $\begin{array}{c}\text { Percentage } \\
\text { Distribution of } \\
\text { Households within } \\
\text { the Operational } \\
\text { Landholding } \\
\text { Category Who } \\
\text { Reported Hiring } \\
\text { Irrigation from Tube } \\
\text { Wells }\end{array}$ & $\begin{array}{c}\text { Number of } \\
\text { Householdswithin } \\
\text { the Operational } \\
\text { Landholding } \\
\text { Category Who } \\
\text { Reported Hiring } \\
\text { Irrigation from } \\
\text { TubeWells }\end{array}$ & $\begin{array}{c}\text { Percentage } \\
\text { Distribution of } \\
\text { Households within } \\
\text { the Operational } \\
\text { Landholding } \\
\text { Category Who } \\
\text { Reported Hiring } \\
\text { Irrigation from } \\
\text { TubeWells }\end{array}$ \\
\hline Small & 102 & 90.7 & 91 & 85.8 \\
Medium & 11 & 9.3 & 13 & 11.4 \\
Large & - & - & 3 & 2.8 \\
All & 113 & 100 & 106 & 100 \\
\hline
\end{tabular}

Source: Compiled by authors.

\section{Conclusions}

Haryana has experienced an absolute boom in ground water irrigation economy over the last four decades. The findings of the study reveal that the density of tube wellsperthousand hectares and number have increased by more than 250 and 300 per cent, respectively, during 1975 to 2013. This tremendous growth clearly demonstrates the increasing role of groundwater in the development of irrigated agriculture. Cost effectiveness of electric tube wells and flat tariff rates are some of the common causes for this rapid growth. A direct consequence of this surge in electric tube wells has been mounting perpetual loss and poor financial health to the State as the gross subsidy provided to electric tube wells is about 45 per cent of the total subsidies available to the farmers. Electricity subsidies to electric tube wellsand their resulting expansion are taking a heavy toll on groundwater levels. During the year 2012-13, more than two- thirds of groundwater depth monitoring wells reported depths greater than five metres and about 62.5 per cent of wells recorded a fall in water levelsfrom the previous year. Surprisingly, in spite of remarkable development in commercial and cooperative banks, these institutions account for about 15 percent of the total loans disbursed for tube well installation. Meanwhile, commission agents, moneylenders and traders are still contributing for more than 50 per cent of the total credit for tube well installationsin Haryana.

The study also discloses that the area under hired irrigation through tube wells in the State is increasing, which is comparatively low (30 per cent farmers buy groundwater for irrigation at national level), therefore, leaving much of the land unirrigated and may cause economic losses to farmers, further affecting the economy of the State. Besides, about 70 percent 
of the tube wells are owned by small farmers followed by medium and large farmers. This finding from the study is contrary to the earlier belief that the benefit of electricity subsidy goes only to large farmers who are most likely to have large number of own electric-tube wells.This belief is very much missing in much of the Haryana State policy discourses and analyses, which has several policy implications. The findings of the study also drive home the point that groundwater markets are no longer a localised small-scale phenomenon found in sporadic pockets here and there in the State, but are indeed an all-pervasive feature in State's agricultural landscape and hence demand more attention than hitherto given. Finally, it is concluded that the groundwater irrigation economy in Haryana is in growth phase and it is important to understand fully the dynamics of this economy before managers and policy makers can begin to think about effectively managing it. 


\section{References}

Bhalla, P (2007), "Impact of Declining Groundwater Levels on Acreage Allocation in Haryana,"Economic and Political Weekly,42,2701-2707.

Bjornlund, H. and J, McKay (2002),"Aspects for Water Markets for Developing Countries: Experiences from Australia, Chile and the US," Environment and Development Economics, 7, 769-795.

Bjornlund, H., Nicol, L. and Klein, K.K (2007), "Challenges in Implementing Economic Instruments to Manage Irrigation Water on Farms in Southern Alberta," Agricultural Water Management, 92, 131-141.

Central Ground Water Board (2013), “Groundwater Year Book,” India.

Chawla,J.K., Khepar,S.D.,Sondhi,S.Kand Yadav,A.K (2010),"Assessment of Long Term Groundwater Behaviour in Punjab, India," Water International, 35, 63-77.

Dubash, N. K (2000), "Ecologically and Socially Embedded Exchange Gujarat Model of Water Exchange," Economic and Political Weekly,35,1376-1385.

Dubey, A and Rai, S.C (2008), "The Groundwater Economy of the Indo-Gangatic Plains, India,"Annals of the National Association of Geographer, India, 28, 51-63.

Hira, G.S (2009), "Water Management in Northern States and the Food Security of India," Journal of Crop Improvement, 23, 136-157.

Moench, M (1992), "Chasing the Water Table: Equity and Sustainability in Groundwater Management," Economic and Political Weekly,27,171-177.

Mukherji, A (2006), "Political Ecology of Groundwater: The Contrasting Case of Water Abundant in West Bengal and Water Scarce Gujarat, India," Hydrogeology Journal, 14, 392-406.

Mukherji, A (2007), "The Energy Nexus and its Impact on Groundwater Markets in Eastern Indo-Gangetic Basin: Evidence from West Bengal, India,"Energy Policy, 35, 6413-6430.

Mukherji, A (2008), "Spatio-Temporal Analysis of Markets for Groundwater Irrigation Services in India: 1976-1977 to 1997-1998," Hydrogeology Journal, 16, 1077-1087.

Prakash, A (2005), “The Dark Zone: Groundwater Irrigation and Water Scarcity in Gujarat,” New Delhi: Orient Longman.

Patle, G.T., Singh,D.K., Sarangi,A., Rai,A., Khanna.A., and Sahoo,N (2015), "Time SeriesAnalysis of Groundwater Levels and Projection of Future Trend," Journal of the Geological Society of India, 85, 232-242.

Raju, B.M.K., Rao, K.U., Venkateswarlu, B., Rao, A.V.M.S., Rama Rao, C.A., Rao, V.U.M., Rao, B.B., Ravi Kumar, N., Dhakar, R., Swapna, N and Latha,P (2013), "Revisiting Climatic Classification in India:A District Level Analysis," Current Science, 115, 492-495.

Saleth, R.M (1996), “Water Institution in India: Economic, Law and Policy,” New Delhi: Commonwealth Publishers.

Scott, C.A. and Sharma, B (2009),"Energy Supply and the Expansion of Groundwater Irrigation in the IndusGanges Basin",International Journal of River Basin Management, 7,1-6. 
Shah, T (1993), "Groundwater Markets and Irrigation Development: Political Economy and Practical Policy," Bombay: Oxford University Press.

Shah, T and Ballabh, V (1997), "Water Markets in North Bihar: Six Village Studies in Muzaffarpur District," Economic and Political Weekly,32,183-190.

Shah, T., Singh, O.P. and Mukherji, A (2006), "Some Aspects of South Asia's Groundwater Economy: Analyses from a Survey in India, Pakistan, Nepal Tarai and Bangladesh," Hydrogeology Journal, 14, 286-309.

Sharma, P. and Sharma, R.C (2004), "Groundwater Markets Across Climatic Zones: A Comparative Study of Arid and Semi-Arid Zones of Rajasthan," Indian Journal of Agricultural Economics, 59, 138-150.

Sharma, S., Tripathi, S and Moerenhout, T (2015), "Rationalizing Energy Subsidies in Agriculture: A Scoping Study of Agricultural Subsidies in Haryana, India," International Institute for Sustainable Development, Manitoba, Canada.

Singh, D (2002), “Groundwater Markets in Fragile Environments: Key Issues in Sustainability," Indian Journal of Agricultural Economics, 57, 180-196.

Singh, $O$ and Amrita (2015), "Groundwater Variability in Haryana: A Spatio-Temporal Analysis," Punjab Geographer,11,13-36.

Singh, $\mathrm{O}$ and Singh, H (2015), "The Response of Farmers to the Flood Hazard under Rice-Wheat Ecosystem in Somb Basin of Haryana, India: An Empirical Study," Natural Hazards, 75, 795-811.

Zhang, L., Wang, J., Huang, J and S., Rozelle (2008), "Development of Groundwater Markets in China: A Glimpse into Progress to Date," World Development, 36, 706-726. 